\title{
Sosyal Mübadele Teorisi Kapsamında Sosyal Taşıma Kapasitesi ${ }^{1}$
}

\author{
Asena ALBAYRAK \\ Dokuz Eylül Üniversitesi \\ asenaalbayrak91@gmail.com \\ https://orcid.org/0000-0003-0021-1417 \\ Arş. Gör. Selim KIROVA \\ Manisa Celal Bayar Üniversitesi \\ selim.kirova@cbu.edu.tr \\ https://orcid.org/0000-0002-9025-6725 \\ https://doi.org/10.37847/tdtad.726750
}

\section{Özet}

Bu çalışmada, Çeşme ilçesinin sosyal taşıma kapasitesinin yerel halkın bakış açısıyla ve sosyal mübadele teorisi prensipleriyle incelenmesi amaçlanmıştır. Çeşme'deki turizm faaliyetlerinin sosyal taşıma kapasitesi ile ilgili değerlendirilmesine dair zengin ve derinlemesine betimlemelerin elde edilmesi amaçlandığından nitel bir araştırma olarak tasarlanmıştır. Bu doğrultuda, Çeşme'de yaşayan yerel halktan 12 katılımcı ile görüşme tekniği kullanılarak yarı yapılandırılmış görüşme formu aracılığıyla mülakat yapılmıştır. Veriler betimsel analize tabi tutulmuştur. Araştırma sonucunda; ilçeye yönelik turistik hareketin, kaynakların adil kullanımı ve toplumun kültürel yapısına etkileri açısından, sosyal taşıma kapasitesini zorlayan çıktılara sebep olduğu tespit edilmiştir. Olumsuz çıtıların aksine ulaşılan sonuçlar, yerel halkın genel değerlendirmesinin, bölgelerinde turizm hareketinin devamını destekler nitelikte olduğu yönündedir.

Anahtar Kelimeler: Sosyal Mübadele Teorisi, Sosyal Taşıma Kapasitesi, Kültürel Etki, Çeşme.

\section{Social Carrying Capacity within the Scope of Social Exchange Theory}

\begin{abstract}
Purpose of this study is examining the social carrying capacity of Çeşme district from the perspective of the local residents and within the scope of social exchange theory principle. It has been designed as a qualitative research as it is aimed to acquire a rich and in-depth description regarding the assessment of social carrying capacity of tourism activities in Çeşme. Accordingly, 12 participants among the local residents of Çeşme have been interviewed through a semi-structured interview form. The data have been subjected to descriptive analysis. As a result of the study; it has been determined that touristic activities in the district give rise to outputs that pressure the social carrying capacity in terms of fair use of resources and impacts on the cultural structure of the society. Despite the negative outputs, results indicate that general behavior of the local residents supports the continuance of tourism activities in the area.
\end{abstract}

Keywords: Social Exchange Theory, Social Carrying Capacity, Cultural Impact, Çeşme.

\footnotetext{
${ }^{1}$ Bu makale, 16-19 Ekim 2019 tarihlerinde Eskişehir'de düzenlenen "20. Ulusal Turizm Kongresi”nde sunulan ve bildiriler kitabında yer alan bildirinin geliştirilmiş halidir.
} 


\section{Giriş}

Sosyal taşıma kapasitesinin yerel halkın turizme olan bakışını, algısını ve hoşgörüsünü ölçtüğü düşünüldüğünde, turizmin olumsuz toplumsal etkilerinden doğan kalabalıklaşma ve kaynakların kıtlaşması gibi nedenlerin sosyal taşıma kapasitesine olumsuz bir etki yapabileceği ortaya çıkmaktadır (Williams ve Gill, 1994). Bu kalabalıklaşma ve ziyaretçi sayısındaki artış, turistin ve yerel halkın bölgeye olan bakışını ve algısını da olumsuz etkilediği düşünülmektedir.

$\mathrm{Bu}$ çalışmada sosyal taşıma kapasitesi ölçümünün sosyal mübadele teorisi kapsamında ele alınmasının nedeni; sosyal mübadele teorisinin sosyal ilişkileri bir tür ödül-alışveriş ekseninde değerlendirmesi ve kişiler arasındaki memnuniyet-tatmin derecesini veya ilişkilerin yürütülüp yürütülmemesi kararını bu ödül-alışveriş bağlamında ölçmesi düşüncesidir. Bu sebeple araştırma, son yıllardaki kontrolsüz turist sayısı artıșına, kişiler arasındaki ilișkilerin kalitesine ve karşılıklı etkileşimine bağlı olarak sosyal taşıma kapasitesini doldurduğu düşünülen Çeşme destinasyonunda gerçekleştirilmiştir (Alkan, 2015).

Çalışmanın amacı bölgenin sosyal taşıma kapasitesi seviyesinin sosyal mübadele çerçevesinde ve ilișkisinde, yerel halkın bakıș açısıyla ölçmektir. "Yerel halkın turistlerle sosyal mübadelesi bağlamında Çeșme'deki sosyal tașıma kapasitesi ne durumdadır?" sorusuyla yola çıkılmıștır. Bu sorunun cevaplanması, gelecekte sürdürülebilir bir turizm hareketini sağlayabilmek açısından ne tür adımlar atılması gerektiğini de ortaya çıkarması açısından önem arz etmektedir.

\section{Turizmde Sosyal Taşıma Kapasitesi}

Seyahate katılan kişi sayısının artması ve çevreyle ilgili değişimlerin meydana gelmesi ile birlikte sürdürebilirlik, son yılların en çok tartıșılan kavramlarından biri haline gelmiștir. Sürdürülebilirlik yaklaşımının temelleri ise "Ortak Geleceğimiz" raporuna da temel oluşturan, Brundlant Raporu'na dayandırılmaktadır (Erdoğan, 2003). Turizm açısından sürdürülebilirlik ise, turizme kaynak olan bölgesel ve yerel çekiciliklerin korunup geliștirilerek devamlılığını sağlamak olarak ifade edilebilir (Avcıkurt, 2003). Buradan hareketle sürdürülebilirliğin insan yaşamının her alanını etkileyen bir kavram haline geldiğini söylemek mümkündür.

Turistik çekiciliği sağlayan doğal ve kültürel değerleri koruma-kullanma dengesi, destinasyonun uzun vadede tercih edilebilirliğini sağlamakla birlikte ekosistemi korumak ve gelecek kuşaklara miras bırakmak bakımından da göz ardı edilemeyecek bir husustur. Bu koruma-kullanma dengesinin nasıl sağlanacağı konusu irdelendiğinde taşıma kapasitesi kavramıyla karşılaşılmaktadır (Demir ve Çevirgen, 2006).

Dünya Turizm Örgütü turistik taşıma kapasitesini; "yerel, çevresel, fiziksel, ekonomik ve sosyokültürel özelliklerin tehlikeye atılmaması ve turist memnuniyetini azaltmaksızın belli bir süre içinde bir yeri ziyaret edebilecek maksimum kişi sayısı" şeklinde tanımlamaktadır (WTO, 1999). Bir başka tanıma göre ise de taşıma kapasitesi; maksimum sayıdaki insanın destinasyondan aldığı hizmette bir kalite azalması görülmeden ve destinasyon çevresinde olumsuz bir etki yaratmadan söz konusu destinasyonu kullanmasıdır (Oral ve Şenbük, 1996). Bu tanımlardan yola çıkılarak turizmdeki taşıma kapasitesi kavramının destinasyonun turizm amaçlı gelişmesinde kaldırabileceği sınırı ifade etmekte olduğu anlaşılmaktadır. Buradaki temel sorun turistik taşıma kapasitesinde niceliksel ölçümün zorluğudur. $\mathrm{Bu}$ noktada "Ne kadar ziyaretçi yeterli olmalıdır?" sorusu önem kazanmaktadır (Uysal ve Baloğlu, 1994). Bu sebeple turizm planlamacıları, çevre üzerinde gerçekleşen değişikliklere sebep olan turist sayısını üst sınır olarak kabul etmektedir (Mexa ve Coccossis, 2004). 
Taşıma kapasitesi kavramının fiziksel, ekolojik, sosyal, psikolojik ve ekonomik olmak üzere farklı boyutları bulunmaktadır. Bu boyutlar turizm gelişimi için ölçülen farklı sınır ve uygulamaları kapsamaktadır (Kozak, 2014). Sosyal taşıma kapasitesi yerel halkın destinasyondaki turistik faaliyetlere karşı olan tutumu, algıları ve memnuniyetleri ile ilgili bir kavram olmakla birlikte (Kozak, 2014) destinasyonda yerel halk tarafindan kabul edilebilir turist sayısını da ele almaktadır (Gee, 1997). Öte yandan literatürde sosyal taşıma kapasitesini turist sosyal taşıma kapasitesi ve yerel toplumun sosyal taşıma kapasitesi olarak ayrı ayrı ele alındığına da rastlanmaktadır. $\mathrm{Bu}$ tanıma göre yerel toplumun sosyal taşıma kapasitesi; yerel halkın geleneklerinin, değerlerinin, normlarının ve yașam kalitesinin hasara uğraması konusunda kabul edilemeyecek sınır olarak belirtilmektedir (Wahab ve Pigram, 1997). Yerel halk ve turist arasındaki ilișkilerde herhangi bir olumsuzluk yaşanması sosyal taşıma kapasitesinde sorun yaşandığı anlamına gelmektedir (Ünlüönen ve Tokmak, 2009).

Turizmin olumsuz etkilerine bakıldığında, kalabalıklaşma, ilişkilerin bozulması, turizmin toplumsal değişimi arttırıcı etkisi ve suç oranın artması sonucu destinasyonun sosyal taşıma kapasitesinde sorunlar meydana gelmektedir (Doğan, 2004; Avc1, 2007).

\section{Sosyal Mübadele Teorisi}

Literatürde sosyal alışveriş teorisi (Özkalp, 2005) olarak da geçen sosyal mübadele teorisi, sosyal taşıma kapasitesi ölçümlerinde kullanılan bir teorik çerçevedir (Gonzalez vd., 2018). Bu kuramın kapsadığı konular ekonomik mübadeleden çok daha geniştir ve sosyal ilişkilerde bir tür kaynak değiş tokuşunu simgeler. Bu kuram sayesinde hem toplum hem de toplumdaki bireyler arası ilişkiler daha iyi anlaşılmaktadır. Kuramın öncüleri olan George Homansve Peter Blaubu anlamda kurama farklı açılardan yaklaşmaktadır. Homans sosyal mübadele teorisini mikro olarak birey düzeyinde ele alırken; Blau ise makro olarak toplum düzeyinde irdeler (Aydın, 2017; Özkalp, 2005).

Kuram, temelde bireyler arasındaki ilişkileri bir tür kaynak mübadelesi olarak ele alır. Diğer bir değişle; insanların sosyal hayatta ilişki kurduğu diğer bütün insanlar ve topluluklarla arasındaki alışverişe dayanan bir iletişim olduğunu savunmaktadır. Bu alışveriş çoğunlukla soyut olmakla birlikte; değer verme, saygı duyma, onur, dikkate alınma gibi davranışları içermektedir (Wallace ve Wolf, 2004). Bu davranışları görmek ödül olarak addedilirken, bu davranışlardan yoksun olmak ilişkilerin maliyetini arttıracaktır. İnsanlar arasındaki ilişkilerin maliyetinin faydayı geçmemesi ilișkilerin ömrünü uzatırken; maliyetin faydayı geçmesi durumunda ilișkiler zayıflayacak veya kopacaktır (Gonzalez vd. 2018). Bu teorinin üç varsayımı bulunmaktadır. İlki akılcılıktır. İnsanların, diğer insanlarla ve gruplarla girdiği ilișkilerinde akılcı hareket ettiklerini ve bir ilișkiden en az zararla ve en yüksek faydayla çımayı beklediklerini ifade eder. İkinci varsayım ekonomi biliminden devşirilen marjinal fayda kavramıdır. İnsan ilişkilerindeki marjinal fayda kendisini insanların ödüllere doygun olup olmadığı ortaya koyularak göstermektedir. Örneğin bir kişi kendisi için çok önemli bir ödülü elde ettikten sonra diğer ödüller onun için bir anlam ifade etmemeye başlayabilir. Üçüncü ve son varsayım ise dengedir. İnsanlar arasındaki alma ve verme dengesine dayanan bu kavram ilişkilerdeki adalet kavramını gündeme getirmektedir. İnsan ilişkilerindeki bu tür bir dengenin bozulması ilişkilerin tamamen kopmasına neden olabilmektedir (Özkalp, 2005).

Sosyal mübadele teorisi, işin içinde insanın var olduğu her alanda olduğu gibi turizmde de kendisine yer bulmaktadır. Turizmde bu kuram, turist ve yerli halk arasındaki ilişki bağlamında incelenmektedir. Yani turist ve yerli halk arasındaki kaynak mübadelesi bağlamında saygi görme, değer verilme, dikkate alınma, önemsenme gibi olgular bu teori temelinde değerlendirilebilmektedir. Bu bahsedilen olgular bazında yerel halk ve turist memnuniyeti ve tatmin 
derecesi; sosyal mübadele kapsamında irdelenen ödül-maliyet alışverişini belirlediği gibi, o bölgedeki sosyal taşıma kapasitesinin düzeyi hakkında da fikir verecektir (Andereck vd., 2005).

\section{Yöntem}

Bu çalışma Çeşme'de yaşayan yerel halkın sosyal taşıma kapasitesi algısını, sosyal mübadeleyle ilişkisi çerçevesinde incelemektedir. Yerel halk ve turist arasındaki ilişkinin irdelenmesi genellikle akla yerel halk ve yabancı turist etkileşimini getirse de Çeşme'ye gelen turistlerin önemli bir kısmı yerli turistlerden oluşmaktadır. Araştırmada yerel halkın tutumunu, algılarını ve düşüncelerini derinlemesine incelenmek amacıyla nitel araştırma yöntemi kullanılmıştır. Bu amaçla "Yerel halkın turistlerle sosyal mübadelesi bağlamında Çeşme'deki sosyal taşıma kapasitesi ne durumdadır?" sorusuyla yola çıkılarak yarı yapılandırılmış görüşme formu ile sorular yöneltilmiştir. Soruların hazırlanmasında, yerel halkın sosyal taşıma kapasitesi algısını, sosyal mübadeleyle ilişkisi çerçevesinde inceleyen çalışmalar bașta olmak üzere sosyal mübadele teorisi literatüründen faydalanılmıştır (Gonzalez vd, 2018; Uehara, 1990; Emerson, 1976). 23-24-25 Temmuz 2019 tarihlerinde Çeşme'ye gidilerek yerel halka ulaşılmıştır. Görüşülen katılımcılara kimlerin bilgi sahibi olabileceği sorularak kartopu örnekleme yöntemiyle toplamda 12 katılımcıya ulaşılarak veri setinin doyuma ulaşması ve tekrara düşen cevaplar nedeniyle görüşmeler sonlandırılmıştır. Katılımcılarla görüşmeler, önceden izin alınarak ses kaydı ve not tutma yöntemiyle kaydedilmiştir. Görüşmeler ortalama 45 dakika sürmüştür. Kaydedilen veriler yazıya geçirildikten sonra temalara ayrılarak betimsel analize tabi tutulmuştur.

Araştırmanın geçerlik ve güvenirliği; iç geçerlik, dış geçerlik ve iç güvenirlik, dış güvenirlik olmak üzere dört ayrı kavramla denetlenmiştir. İç geçerlik kavramı kapsamında katılımcı teyidi yöntemi uygulanmıştır. Dış geçerlik kapsamında elde edilen bulgular doğrultusunda araştırma sonucunun benzer durumlara uyup uymadığını anlayabilmek için sosyal taşıma kapasitesi ve sosyal mübadele teorisi ilişkisini farklı destinasyonlarda inceleyen çalışmalara ihtiyaç duyulmaktadır. Benzer çalışmalarla karşılaştırılma yapılabilmesi için, araştırmanın örneklemi, ortamı ve süreçleri açıkça belirtilmiştir. İç güvenirlik kapsamında araştırmada literatüre bağlı olarak veri analizini gerçekleştirmek amaçlanmıştır. Literatür bölümünde verilen başlıklardan ve tanımlardan yola çıkarak elde edilen bulgular düzenlenmiş ve açıklanmıştır. Dış güvenirlik kapsamında ise katılımcıların kafalarında soru işaretine yer bırakmamak için görüşmelerden önce araştırmacılar konumlarını ve amaçlarını açıkça belirtmiştir.

\section{Bulgular}

Araştırmaya katılan yerel halka ilișkin demografik bilgiler Tablo 1'de sunulmaktadır.

Tablo 1. Yerel halka ilişkin demografik bilgiler

\begin{tabular}{|l|c|c|c|c|c|}
\hline & Cinsiyet & Yaş & Ĕğitim & Meslek & Gelir \\
\hline Katılımcı 1 & Erkek & 75 & Lisans & Emekli & 5000 üstü \\
\hline Katılımcı 2 & Kadın & 47 & İlkokul & Esnaf & 5000 üstü \\
\hline Katılımcı 3 & Erkek & 67 & Lise & Emekli & $2000-5000$ aras1 \\
\hline Katılımcı 4 & Erkek & 86 & Ilkokul & Emekli & 5000 üstü \\
\hline Katılımcı 5 & Kadın & 33 & Doktora & Turizmci & $2000-5000$ aras1 \\
\hline Katılımcı 6 & Erkek & 40 & Lise & Belediye Çalışanı & $2000-5000$ aras1 \\
\hline Katılımcı 7 & Erkek & 45 & Lisans & Belediye Çalışanı & $2000-5000$ aras1 \\
\hline Katılımcı 8 & Erkek & 37 & Lise & Belediye Çalı̧̧anı & 5000 üstü \\
\hline Katılımcı 9 & Erkek & 50 & Lise & Esnaf & 5000 üstü \\
\hline Katılımcı 10 & Erkek & 32 & Lise & Esnaf & 5000 üstü \\
\hline Katılımcı 11 & Kadın & 45 & İlkokul & Esnaf & 5000 üstü \\
\hline Katılımcı 12 & Kadın & 28 & Lisans & Çalışmıyor & - \\
\hline
\end{tabular}


Verilerin analizinde, nitel araştırma analiz tekniklerinden olan betimsel analiz yöntemi kullanılmıştır. Görüşme metinleri, araştırma ekibinde görev alan araştırmacılar tarafından ayrı ayrı değerlendirilmiş ve ardından kodlama işlemi yapılmıştır. Görüşme metinlerinin betimsel analizi sonucunda "kaynak yaklaşımı" ve "sosyal etkileşim yaklaşımı" olmak üzere iki ana tema ortaya çıkarılmıştır. Sosyal taşıma kapasitesinin, sosyal mübadele teorisi prensipleriyle incelenmesinde özellikle öne çıkan hususların başında bölge kaynakları ve bunların adil kullanımı gelmektedir. Hem somut hem de soyut kavramların birleşiminden oluşan bölge kaynakları, yapılan görüşmelerde de sıkça vurgulanan konuların başında gelmiş ve "kaynak yaklaşımı" şeklinde temalandırılmıştır.

Katılımcılarla yapılan görüşmelerde, bölgeye yönelik turistik faaliyetlerin etkileri konusunda; bölge ve yerel halkın sahip olduğu kültür, fiziksel ortam, ürün ve hizmet özellikleri ve kaynakların niteliği ön plana çıkmıştır. Bu etkilerin değerlendirilmesinde sıkça bahsedilen hususlar ise, yerel halk ve yaşantıda bozulmalar, esnaf ahlakıyla ilgili kaygılar, turistik fiyat artışları, kalabalık, gürültü ve çevre kirliliği gibi sebeplerle kaynakların adil kullanımı konusunda yaşanan sıkıntılar olmuştur.

Bölgedeki turistik faaliyetler sebebiyle ortaya çıkan ve yerel halkın yaşantısında çeşitli çıktılarla gözlenebilen kültürel etki, kaynak yaklaşımı teması altında değerlendirilen ilk öğedir. Kültür öğesinin kaynak yaklaşımı başlığı altında değerlendirilmesinin sebebi, bir bütün olarak düşünüldügünde yerel halkın sahip olduğu kültürel öğelerin en önemli kaynaklardan biri olarak öne çıkmasıdır. Bununla ilgili görüşlerde özellikle vurgulanan konuların başında, yerel halk ve yaşantıda meydana gelen değişim gelmektedir. Veriler incelendiğinde, katılımcıların yerel halkı tanımlamada sıkıntı yaşadığ görülmektedir. Bununla ilgili bazı katılımcı ifadeleri aşağıda gösterilmiştir;

"Alaçatı halkı nasıl olur diye sorarsanız bana ben kafamda net bir şey söyleyemiyorum. Bu anlamda onun korunmadığını düşünüyorum. Yerel halk görüntüsü yok kafamda Çeşme deyince Alaçatı deyince... Sizce yerel halk nerede Alaçatı'da? Şu an bence esnaf bile yerel halk değil. Şu an tezgâh açan şu an otel işletenler, bu popülariteyi yakalayıp buraya gelip para kazanmak isteyen insanlar. Nerde yerel halk? Arka tarafta genelde. Turistlerin yüz yüze olduğu kişiler yerel halk değil Çeşmeli değil bence." (K5)

"Bence işin içine bu kadar para menfaat girince insan ilişkilerindeki o naiflik kibarlık gidiyor. Anlatıyor babalarımı mesela burası köydü herkes birbirini tanırdı vs. diye. Şimdi hiçbir şekilde öyle değil. Yazın burada olan mekan sahipleri kışın yok. Yani yazın burayı tanımlarsan bir ege kasabası değil. İstanbul'un zengin bir ilçesi gibi..." $(k 12$

Yukarıdaki görüşler incelendiğinde dikkat çeken unsurlardan bir diğeri, yerel halkın, bölgedeki esnaf ve işletme yapılanmasında ve turizmin maddi getirilerinden faydalanmada geri planda kalmasıdır. Bu bağlamda değerlendirildiğinde, sosyal mübadele teorisinin temel argümanlarından olan, ilişkilerdeki ödül beklentisinin karşılanıp karşılanmadığı konusu da bir soru işareti olarak not alınmalıdır. Diğer taraftan, turistik faaliyetlerin gelir sağlayıcı etkisini kötüye kullanan esnafların varlığına yönelik bulgular, yerel halkı içine alsın ya da almasın kültürel bir erozyonu işaret eder niteliktedir. Örneğin;

Gelenleri (turistleri) affedersin sağllacak inek gibi görüyorlar. Rakamlar yükseliyor. Sözgelimi bir kumru; biz devaml olduğumuzdan bize ayrl fiyat turiste ayrı fiyat... (Çeşme) Pahalı bir yer.(k1) 
Kaynak yaklaşımı altında değerlendirilen bir diğer öğe; turistik fiyat artışları, kalabalık, gürültü ve çevre kirliliği nedeniyle kaynakların adil kullanılamamasıdır. Bu noktada dikkat çeken husus; yiyecek-içecek işletmeleri ve özel işletmelerin kullanımında olan plajlar gibi ürün, hizmet ve doğal değerleri kapsayan yöre kaynaklarında aşırı fiyatlama öğesinin; çevresel kullanımı (yürüyüş, gezip görme ve dinlenme) kapsayan kaynaklarda ise kalabalık, gürültü ve çevre kirliliği öğelerinin ön plana çıkmasıdır. Diğer taraftan, özel işletmelerin kullanımında olmayan kumsal ve plajlarda da kirlilik ve kalabalık sebebiyle yöre halkı açısından adil kullanım sorunlarıyla karşılaşıldığı belirtilmiştir.

Konuyla ilgili görüşler incelendiğinde, turizm kaynaklı fiyatlamaların, pek çok hizmet ve üründen adil ve eşit bir şekilde yararlanma konusunda yerel halkın alım gücünü aşacak boyutlarda olduğu görülmektedir. Bu noktada görüşler, bu hizmet ve ürünlerden yararlanmayı isteyip yararlanamama ve tercih etmeme şeklinde ikiye ayrılmıştır. Örneğin;

“(Alaçatı'ya) daha çok ünlüler gidiyor zaten, oraya senin benim gitmem mümkün değil. Çok pahalı, inanılmaz. Yolacak kaz hesabı yapıyorlar.” (k10)

"Yani açıkçası hiç tercih etmiyoruz bunu bildiğimiz için. Biz böyle bir bilgiye sahibiz. Oradaki menülerin oradaki fiyatların yemeklerin çok yüksek olduğunu biliyoruz. Hadi gidip Alaçatı'da işte şu mekânda şunu yiyelim şunu yapalım gibi bir şey yapmıyoruz açıkçası. Çünkü biliyoruz gereksiz bir pahalılık var." (K5)

Kalabalık algısı, gürültü ve çevre kirliliği konularında hemen tüm katılımcıların görüşü, özellikle günübirlikçiler olmak kaydıyla temel sebebin turizm kaynaklı olduğu yönündedir. Bu noktada, sosyal taşıma kapasitesi açısından düşündürücü olan ve sosyal mübadeledeki adalet duygusunu zedeleyebilecek durum, yerel halkın kendi yaşam alanını beğenmez ve kullanmaktan uzak durur hale gelmesidir. Aşağıda bununla ilgili bazı katılımcı örnekleri yer almaktadır.

"Ben gidemiyorum. Ot festivalinde mesela müthiş bir kalabalık var. 11.5 milyon kişi geliyor. Etten kale yürüyemezsiniz. O kalabalığın içine girilmez ki Otobüse binmek mesele arabanı park etmek mesele."(K11)

"Bir kere halk plajlarına sezon içinde kaç yıldır hiç gitmiyorum. Hafta içi de gitmiyorum ben yine de kalaballk. Kalabalıktan, pislikten ikisi de" (K12)

"Pazar denize gidecek olsam arkadaşlarla biz Urla'da papaz koyu var arazi araçlarlyla oraya gidiyoruz. Sessiz, kimseler yok bedava. Bunların hepsinden güzel git balık tut, denize gir, takıl. Buradaki plajlarda toplasan 10 kişi bulamazsın Çeşmeli veya Alaçatılı." (K10)

Kaynak yaklaşımı teması altında ele alınan ve sosyal taşıma kapasitesini zorlayan durumlara rağmen özellikle belirtilmesi gereken nokta, katılımcıların önemli bir kısmının, bölgeye yönelik turistik hareketi desteklediğidir. Turistik hareketin yarattığı ve kaynak yaklaşımı açısından belirtilen sıkıntılar sebebiyle sosyal taşıma kapasitesinin aşıldığını düşünen katılımcılarda mevcut olmasına karşın turiste ve turizme yönelik sert bir duruş söz konusu olmamıștır. Așağıya, konuyla ilgili bazı katılımcı ifadeleri yansıtılmıştır;

"Bu yoğunluk olmasa turistler burayı tercih etmese, ben mesela şu an çalışmıyorum eșim çalışıyor olmasa belki o da işini kaybedecek. Çünkü eşimin işi turizmle alakalı. Bu nedenle de biz aslinda onu (olumsuzluklarl) da tolere edebiliyoruz bir yere kadar. (...) Çok basit bir örnek, sahilde yürümeyi çok seviyoruz ama onu yapmıyoruz son dönemlerde (kalabalık yüzünden). Ama turistlere bir kızgınlığım yok. Ama şöyle bir şey 
var şunu düşünüyoruz biz. Biz buraya turistin gelmesini istiyoruz. Kazanç için. Şu an ben şunları konuşurken arka planda eşimin çalıştığını düşünüyorum. Aksi halde çok rahatsiz oluyorum keşke gelmeseler' vs diyebilirdim ama şu an bunu konuşurken eşimin turizmci olduğunu düşünüyorum. " $(k 5)$

"Tabii burada pek çok işletme turizmden kazanıyor. Kalabalık ve hareketli olmasını da bazen güzel oluyor ama çok kalabalık olduğunda bu irrite etmeye başlıyor. Bazen çok kalabalı oluyor o zaman keşke gelmeseler diyorum ama bu kadar gelmeseler manasında. Kışın da mesala çok sessiz her yer kapalı falan o da güzel olmuyor. Denge istiyorum ben."(K12)

Çeşme ilçesinin turizmde sosyal taşıma kapasitesinin yerel halkın bakış açısıyla ve sosyal mübadele teorisi prensipleriyle incelenmesinde ortaya çıkan ikinci ana tema "sosyal etkileșim yaklaşımı" olmuştur. Sosyal taşıma kapasitesinin aşılmasında en önemli faktörlerden biri yerel halk ile turistler arasındaki iletişimin bozulması durumudur (Avcıkurt, 2003). Diğer taraftan, sosyal mübadelede ödül-maliyet dengesini belirleyen saygı, değer verilme ve güven gibi pek çok kavram da bu etkileşimin boyutlarıyla ortaya çıkmaktadır. İki taraf arasındaki iletişimde güven ve saygı ile etkileşimin boyutuyla ilgili bulgular bu tema altında değerlendirilmiştir.

Yerel halkın bölgeye gelen turistlere yönelik güveninin hangi boyutta olduğuna dair yapılan analizler, bu konuda herhangi bir sorun olmadığını göstermektedir. Ayrıca iki taraf arasında saygı, görgü ve yaşam tarzı anlamında da önemli problemler olduğuna dair bir bulguya rastlanmamıştır. Katılımcıların hemen hepsi bölgeye gelen turistlere yönelik güven veya saygıya dayalı bir sorun yaşamadığını açıkça dile getirmiştir. Örneğin;

"Güvensizlik duymuyorum açıkçası. Dışarı çıkınca bir şeyler sorduklarında iletişim oluyor ama herhangi bir güvensizlik veya rahatsızlık olmuyor." ( $k 5)$

Yerel halk ile bölgeye gelen turistler arasındaki etkileşim ve iletişimin boyutuyla ilgili veriler incelendiğinde, kimi sınırlılıklar dikkat çekicidir. Görüşmeler sonucu, katılımcıların önemli bir kısmının, bölgeye gelen turistlerle herhangi bir iletişiminin olmadığı saptanmıştır. Bu durumun iki temel sebebe dayandırıldığı belirtilmelidir. İlki, bölgeye gelen turistlerin önemli bir kısmının günübirlikçi olması ve bu sebeple de iletişim kurulacak herhangi bir firsat ve ortamın oluşmaması durumudur. İlgi çekici olan diğer neden ise, yerel halkın yerli turistleri yüksek egolu bularak iletişime uygun görmemeleridir. Ancak belirtilmelidir ki, bu durum iletişimi kısıtlı tutmasına karşın yerel halk için kayda değer bir sorun olarak görülmemektedir. Her iki konuyla ilgili görüşler, birer örnek ile aşağıda gösterilmektedir;

"Temas kurulmuyor pek fazla. Neden kurulmuyor? Çünkü buraya gelen yerli turist günübirlik gelen turistler genelde. Onlardan çok nadiri birkaç kişi Alaçatı değil buradaki pansiyonlarda kalırlar. Onun için de onlarla iletişim kurma olayı öyle pek yok yani.” (k3)

"Benim çok fazla iletişimim yok aslında ama bazıları çok burnu havda tipler bunu anllyorsun hareketlerinden. Gençlerde burnu havada çok tip var. Arkadaşlık kurmayı tercih etmem kesin olarak." (k12)

\section{Tartışma ve Sonuç}

$\mathrm{Bu}$ çalışmada, Çeşme ilçesinde, turizm hareketi sebebiyle sosyal taşıma kapasitesinin aşılıp aşılmadığı, yerel halk gözüyle ve sosyal mübadele teorisi prensipleriyle incelenmiştir. Ulaşılan 
sonuçların genel bir değerlendirmesi yapılacak olursa; ilçeye yönelik turistik hareketin, özellikle kaynakların adil kullanımı ve toplumun kültürel yapısına etkileri açısından, sosyal taşıma kapasitesini zorlayan çıktılara sebep olduğu görülmektedir. Ancak, olumsuz çıktıların aksine, yerel halkın, bölgelerinde turizm hareketinin devamını desteklediği sonucuna ulaşılmıştır. Bu çelişkiyi, çeşitli argümanlarla tartışarak ele almak yerinde olacaktır.

$\mathrm{Bu}$ sonucun temel sebeplerinden biri; bölgenin, turizm kaynaklı ekonomik getiriye oldukça bağımlı bir hale gelmiş olması olabilir. Sosyal mübadele teorisi, ekonomi disiplininden pek çok doktrini barındırmaktadır ve iki grup arasında ortaya çıkan değiş tokuş (sosyal, ekonomik, kültürel...), fayda maliyet prensiplerine göre değerlendirilmektedir (Uehara, 1990). Konuyla ilgili çalışmalar incelendiğinde; bir turizm destinasyonunda, yerel halk turizmin getirilerinden ekonomik açıdan doğrudan fayda sağlıyor ise (Örneğin, konaklama işletmesinde çalışan bir yerel) turistik hareketin devamını hatta daha da gelişmesini desteklemektedir (Haralambopoulos ve Pizam, 1996; Lankford ve Howard, 1994). Bu bağlamda, çalıșmaya konu olan bölgede, yoğun turizm hareketinin ortaya çıkardığı ve sosyal taşıma kapasitesini zorlayan durumların (örneğin; eşitsizlik, kaynakların kullanılamaması, çevre ve kültürdeki bozulmalar) varlığına rağmen, turizmden doğrudan faydalanan yerel halkın elde ettiği ekonomik getiri, sosyal maliyeti aşmaktadır. Ayrıca, turizm hareketinden dolaylı ekonomik fayda sağlayanların da (örneğin, aile bireylerinden birinin turizmden kazanç elde etmesi) turizmin olumsuz etkilerini görmezden gelebildiğine dair kanitlar mevcuttur (Glasson, 1994).

Konunun tartışılması gereken bir diğer unsuru, turizmden ekonomik olarak fayda sağlamayan ve bölgeye yönelik turistik hareketin sosyal taşıma kapasitesini zorlayan çıktılarına rağmen turiste ve turizme yönelik tavrı olumlu olan bireylere dair sonuçlardır. $\mathrm{Bu}$ durum da birkaç farklı bakış açısıyla ele almaya müsaittir. Bunlardan ilki, bölgeye yönelik turizm hareketinin birey olarak kendisine fayda sağlamaması ve hatta kaynaklardan faydalanmada eşitsiz ve adaletsiz durumlar oluşmasına karşın, genel olarak bölge halkına ve topluma fayda sağladığının değerlendirilmesi durumunda, bireysel çıktılar göz ardı edilerek turizme destek verilmesi veya reddedilmemesi durumudur (Andereck ve Vogt, 2000). Bu durum, sosyal mübadele teorisinin, bireysel olmaktan çok toplumsal bir süreci işaret etmesi (Emerson, 1976) ve bireyin değiş tokuștaki fayda maliyet analizini kendi değerlerindense toplum için ve toplum içinde ortaya çıkan işbirliği ve zorunluluk ilişkileriyle değerlendireceği (Uehara, 1990) savıyla da desteklenmektedir.

Konuyla ilgili bir diğer bakıș açısı, genel bilgi düzeyi üzerinden yürütülmüștür. Buna göre, turizmin ortaya çıkardığı bozucu etki ve zararların ne boyutta algılandığı ve ne kadar gündeme getirildiği, sosyal taşıma kapasitesine yönelik eşiği etkilemektedir. Bölge halkı, turizmin yaratmış olduğu olumsuz etkileri kamuoyu nezdinde tartışılır kıldığında ve toplumsal farkındalık arttığında, turizm hareketine yönelik yaklaşımın da olumsuz olacağı yönünde bulgular mevcuttur (Liu vd, 1987). Bu anlamda düşünüldüğünde, bu çalışmaya konu olan bireyler için, fayda maliyet ilişkisindeki dengenin ölçülemiyor olması da olası bir durumdur.

Çalışmada değerlendirilen bir diğer boyut, yerel halk ile bölgeyi ziyaret eden turistler arasındaki sosyal etkileşim olmuştur. Genel sonuçlar, iki taraf arasında yerel halkın bakış açısına göre güven ve saygı açısından herhangi bir sorunlu durum olmadığını göstermektedir. Güven ve saygı unsurlarının, sosyal mübadeledeki alışveriște en temel faktörlerin başında geldiği düşünüldüğünde (Emerson, 1976) sosyal taşıma kapasitesinin aşılmaması açısından bu iki öğeye ilişkin sonuçların olumlu bir çıktı olarak değerlendirilmesi gerekmektedir. Diğer taraftan, iki taraf arasında iletişimin oldukça sınırlı olduğu tespit edilmiştir. Sonuçlar, iletişimin sınırlı olmasında, ziyaretçilerin ziyaret amacının ve kişilik özelliklerinin (yerel halkça algılanan) rolü olduğunu göstermektedir. 
Bölgeye yönelik turizm hareketinde kitlesel bir payı olan günübirlikçilerin yerel halkla kısıtlı teması, karşılıklı ilişkiyi azaltmaktadır. Bu durum, sosyal taşıma kapasitesini olumsuz etkileyebilecek bir özellik olarak değerlendirilmelidir. Zira, kalabalık algısı sosyal taşıma kapasitesini son derece olumsuz etkileyen bir öğedir (Graefe vd. 1984). Diğer taraftan, sonuçlar, aradaki ilişkinin sınırlı kalmasında, yerel halkın ziyaretçileri yüksek egolu olarak değerlendirmesinin de payı olduğunu göstermektedir. Bu bakış açısının da, doğru olsun ya da olmasın sonuçları olumsuz olacaktır. Sosyal mübadele teorisince, iki taraf arasındaki ilişkilerin temeli, sosyal olarak alışverişi mümkün kılacak bir yapıya oturmuş olmalıdır. Aksi durumlarda, sürdürülebilir bir değişim süreci mümkün olmayacaktır (Emerson, 1976).

\section{Kaynakça}

Alkan, C. (2015). Sürdürülebilir Turizm: Alaçatı Destinasyonuna Yönelik Bir Uygulama. Journal of Yasar University, 10(40): 6692-6710.

Andereck, K.L. ve Vogt, C.A. (2000), "The relationship between residents' attitudes towardt ourism and tourism developmentoptions", Journal of Travel Research, Vol. 39 No. 1, pp. 27-36.

Andereck, K. L.,Valentine, K. M., Knopf, R. C. ve Christine, V. (2005). Residents' Perceptions of CommunityTourismImpacts. Annals of TourismResearch, 32(4): 1056-1076.

Avcıkurt, C. (2003). Turizm Sosyolojisi, Turist-Yerel Halk Etkileşimi. Detay Yayınc1lık: Ankara.

Avcı, N. (2007). Turizmde Taşıma Kapasitesinin Önemi. Ege Akademik Baklş, 7(2): 485-501.

Aydın, E. (2017). Kültür Bağlamında Sosyal Mübadele: Kuramsal Bir Çalışma. International Journal of EconomicandAdministrativeStudies, 16. UIK Özel Sayıs1: 547-562.

Demir, C. ve Çevirgen, A. (2006). Turizm ve Çevre Yönetimi: Sürdürülebilir Gelişme Yaklaşımı. Nobel yayın dağıtım: Ankara.

Doğan, H., Z. (2004). Turizmin Sosyo-Kültürel Temelleri.Detay Yayıncılık: Ankara.

Emerson, R.M. (1976), “Socialexchangetheory”, AnnualReview of Sociology, Vol. 2 No. 1, pp. 335-362.

Erdoğan, N. (2003), Çevre ve (eko)turizm. Erk Yayıncıllk: Ankara

Gee, C., Y. (1997). International Tourism: A Global Perspective. World TourismOrganization, Spain.

Glasson, J. (1994), “Oxford: a heritagecityunderpressure”, Tourism Management, Vol. 15 No. 2, pp. 137-144.

Gonzalez, V. M.,Coromina, L. ve Gali, N. (2018). Overtourism: Residents' Perceptions of TourismImpact As An Indicator of ResidentSocialCarryingCapacity - Case Study of A Spanish HeritageTown. TourismReview, 73(3): 277-296.

Graefe, A. R.,Vaske, J. J., veKuss, F. R. (1984). Socialcarryingcapacity: An integrationandsynthesis of twentyyears of research. LeisureSciences, 6(4), 395-431.

Haralambopoulos, N. andPizam, A. (1996), "Perceivedimpacts of tourism", Annals of TourismResearch, Vol. 23 No. 3, pp. 503-526.

Kozak, M. (2014). Sürdürülebilir Turizm: Kavramlar- Uygulamalar.Detay yayıncılık: Ankara.

Lankford, S.V. ve Howard, D. R. (1994), "Developing a tourism impact attitude scale", Annals of Tourism Research, Vol. 21 No. 1, pp. 121-139.

Liu, J.,Sheldon, P. ve Var, T. (1987), "Residentperception of theenvironmentalimpacts of tourism”, Annals of TourismResearch, Vol. 14 No. 1, pp. 17-37.

Mexa, A. ve Coccossis, H. (2004). TourismCarryingCapasity: A TheoriticalOverview. The Challenge of TourismCarryingCapasityAssesment: TheoryandPractice. Aldershot: Asgate.

July-2020 Vol:5 No:1 International Journal of Turkic World Tourism Studies 
Oral, S. ve Şenbük, U. (1996). Turistik Yörelerin Sürdürülebilir Turizm Açısından Yapısal Değerlendirilmesi, Dünya Şehircilik Günü Kolokyumu Kasım 1995, Alanya. Mimar Sinan Üniversitesi Maatbaası: İstanbul, ss:197-205.

Özkalp, E. (2005). Sosyolojiye Giriş. Ekin Kitabevi Yayınları: Bursa. 14. Baskı.

Uehara, E. (1990), "Dual exchangetheory, socialnetworks, andinformalsocialsupport", AmericanJournal of Sociology, Vol. 96, No. 3, pp. 521-557.

Uysal, M. ve Baloğlu, Ş. (1994). Destinasyonun Yaşam Süresi İle Taşıma Kapasitesi Arasındaki İlişki. Anatolia Ocak-Haziran, Ankara.

Ünlüönen, K. ve Tokmak, C. (2009). Topkapı Sarayında Çalışanlar ve Ziyaretçilerin Sosyal Taşıma Kapasitesine Yönelik Değerlendirmeleri. İşletme Araştırmaları Dergisi, 1(1): 17-30.

Wahab, S. ve Pigram, J., J. (1997). TourismandSustainability. Tourism, Development andGrowththe Challenge of Sustainability, Routledge: Londonand New York.

Wallace, R. A. ve Wolf, A. (2004). Çağdaş Sosyoloji Kuramları. Elburuz L. ve Ayas M. R. (Çev.), Punto Yayıncılık: İzmir.

Williams, P., W. ve Gill, A. (1994). TourismCarryingCapacity Management Issues. Global Tourism: NextDecade. Butterworth-Heinemann: London.

WTO (1999). Global code of ethicsfortourism.Proceedings of Thirteenthsession of General Assembly: Santiago, Chile. 